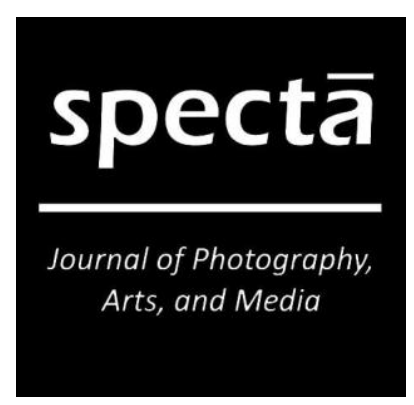

Volume 2 Nomor 1, Mei 2018: 1-12

\section{DAMPAK FOTOGRAFI JURNALISTIK DI SURAT KABAR NASIONAL PADA MASA KAMPANYE PEMILIHAN DAERAH DKI JAKARTA DALAM MEMENGARUHI PEMILIH}

\author{
Ignasius Liliek Senaharjanta Fakultas \\ Ilmu Sosial dan Humaniora Universitas \\ Bunda Mulia (UBM) Jakarta Surel: \\ ignatiusliliek@gmail.com
}

\begin{abstract}
Abstrak
Penelitian ini memiliki tujuan untuk melihat seberapa besar dampak foto jurnalistik dalam memengaruhi pemilih, terutama pada masa pemilihan umum kepala daerah DKI Jakarta putaran kedua. Penelitian ini menggunakan pendekatan kualitatif. Kerangka teoretis dalam penelitian ini menggunakan konstruksi sosial dan agenda setting untuk mengetahui bagaimana media melakukan konstruksi pada saat melakukan pemberitaan pada masa kampanye pemilihan kepala daerah DKI Jakarta. Berdasarkan hasil penelitian dan pembahasan, dapat disimpulkan bahwa surat kabar Kompas dan Republika dalam memublikasikan pemberitaan pemilihan kepala daerah DKI Jakarta memiliki agenda yang berbeda. Kompas, dalam pemberitaannya tampak memihak kepada salah seorang kandidat calon kepala daerah, namun masih memberikan porsi seimbang untuk publikasi dari pasangan kandidat calon kepala daerah yang lain. Sementara itu, Republika memberikan perhatian lebih terhadap salah satu pasangan kandidat calon kepala daerah DKI Jakarta. Pemberitaan yang ditampilkan dalam bentuk visual foto jurnalistik banyak didominasi oleh pasangan salah satu calon kepala daerah DKI Jakarta. Foto jurnalistik akan memiliki dampak atau pengaruh untuk membentuk opini publik atau pemilih, apabila foto mengenai sebuah isu diberitakan secara terus-menerus oleh media.
\end{abstract}

Kata kunci: foto jurnalistik, pilkada DKI, konstruksi sosial, agenda setting

\begin{abstract}
The Impacts of Photojournalism in Local Newspaper During The Jakarta Regional Head Election Campaign in Influencing The Voters. This research aims to analyze the impact of photojournalism in influencing the voters especially during the regional head election on the second round. This research was conducted using qualitative method. The theoretical framework used in this research was social construction and agenda setting to analyze how the media have constructed the news and published it during the regional election. Based on the result and the discussion of this research, it could be concluded that Kompas and Republika newspaper had different agenda in publishing news on Jakarta regional election. Kompas, although seems to tend on one of the candidates, still published proportional information for both candidates, whereas Republika gave more portion towards one specific candidate. The publication presented on the newspaper especially photos of one specific candidate dominated the news release. Photojournalism will give impacts and influences for the voters' public opinion when it is published continuously by the media.
\end{abstract}

Keywords: photojournalism, Jakarta regional election, social construction, agenda setting 


\section{PENDAHULUAN}

Kebebasan pers yang dimulai pada masa era Reformasi telah memberikan dampak positif terhadap media massa. Salah satunya adalah media massa bebas melakukan peliputan dan memublikasikan apa pun tanpa merasa takut harus disensor atau diberedel oleh penguasa. Euforia keterbukaan informasi juga membuka kesempatan kepada masyarakat untuk memanfaatkan media massa secara luas baik dalam menyampaikan sikap dan kritik terhadap pemerintah maupun hak untuk mendapatkan informasi secara terbuka dan proporsional. Organisasi masyarakat dan partai-partai politik juga turut merasakan dampak dari kebebasan pers tersebut. Partai politik memanfaatkan media untuk memublikasikan visi, misi dan programprogram partai. Kondisi baru ini secara tidak langsung memberikan efek positif, yaitu meningkatkan kepedulian dan pengetahuan masyarakat terhadap perkembangan isu-isu terbaru dalam panggung politik.

Keterbukaan informasi turut membuat media massa kembali memegang peranan penting dalam kehidupan hukum, sosial, politik, dan ekonomi. Dengan demikian, kondisi tersebut menyebabkan pemberitaan yang dilakukan media mengalami perubahan. Jika sebelumnya pada zaman Orde Baru media cenderung dimanfaatkan penguasa sebagai corong pemerintah, pada era Reformasi media melakukan fungsinya sebagai "watchdog" atau pengawas dari kebijakan-kebijakan yang dikeluarkan pemerintah maupun institusi lain yang bekerja sama dengan pemerintah.

Media sebagai saluran komunikasi sudah menjadi bagian yang tidak terpisahkan dalam demokrasi. Media berperan dan memiliki fungsi sebagai pilar keempat dalam demokrasi, setelah legislatif, eksekutif, dan yudikatif. Melihat perannya yang begitu penting, media tidak saja menjadi bagian integral dalam politik tetapi sekaligus memiliki posisi sentral. Hal ini karena sifat media yang memiliki jangkauan sangat luas untuk menyebarkan informasi secara masif. Oleh sebab itu, media masih menjadi saluran komunikasi yang utama untuk menyebarkan informasi mengenai kebijakan-kebijakan pemerintah, berita politik, ekonomi, dan lain sebagainya.

Media dimanfaatkan karena fungsinya yang sangat strategis tersebut sehingga keberadaannya pun dimanfaatkan pula oleh partai politik. Partai politik menggunakan berbagai macam saluran media seperti media cetak, elektronik dan online (daring) untuk menyampaikan visi, misi, dan program-program partai kepada masyarakat luas. Hal ini terutama terjadi pada saat menjelang pemilihan Presiden dan Wakil Presiden (Pilpres) atau menjelang pemilihan kepala daerah (Pilkada). Pemberitaan terkait politik cenderung meningkat pada masa-masa tersebut. Peningkatan tersebut seiring dengan antusiasme media dalam memberitakan hasil peliputan elite politik dan programnya kepada masyarakat. Bahkan, sejumlah media cetak atau elektronik menyediakan "spot" atau halaman khusus untuk liputan Pilpres dan Pilkada.

Bentuk pemberitaan yang kerap disajikan oleh media tidak saja ditampilkan dalam bentuk video, teks, atau, narasi, tetapi juga dalam bentuk visual seperti fotografi. Hal ini karena fotografi merupakan salah satu elemen visual yang tidak bisa dipisahkan dari media, khususnya media cetak. Melalui fotografi jurnalistik, berbagai peristiwa dapat direkam, 
didokumentasikan, dan disajikan kepada khalayak melalui berbagai saluran seperti surat kabar, majalah, dan online. Kekuatan fotografi jurnalistik tidak saja terletak pada visualnya yang dapat memberikan gambaran realis tentang sebuah peristiwa, tetapi lebih dari itu fotografi juga memiliki kekuatan verbal berupa teks atau caption yang dapat memperjelas makna dari pemberitaan.

Berdasarkan hal tersebut, penelitian ini ingin mengukur seberapa besar dampak foto jurnalistik pada era kebebasan pers terutama pada pemberitaan masa kampanye pemilihan Kepala Daerah DKI Jakarta putaran kedua dalam memengaruhi pemilih. Penelitian ini dilakukan dengan menganalisis publikasi sejumlah foto jurnalistik dalam dua surat kabar nasional yang memuat foto-foto kampanye pasangan calon Gubernur DKI Jakarta. Permasalahan yang ingin diangkat melalui penulisan makalah ini adalah: (1) bagaimana dampak foto jurnalistik memengaruhi opini pemilih dan

(2) bagaimana proses konstruksi realitas dilakukan media.

Tujuan dari penelitian ini adalah untuk melihat seberapa besar dampak foto jurnalistik dalam memengaruhi pemilih dalam pemilihan umum kepala daerah DKI Jakarta putaran kedua. Penelitian pengaruh foto jurnalistik terhadap pilkada DKI Jakarta ini diharapkan dapat memberikan gambaran tentang kekuatan atau dampak yang dihasilkan dari foto-foto jurnalistik yang disajikan oleh media.

Teori agenda setting digagas kali pertama oleh McCombs dan Shaw pada 1972 (Littlejohn, Stephen W. \& Foss, 2008). Melalui teori ini, McCombs dan Shaw berusaha menjelaskan tentang proses dampak media atau efek komunikasi massa terhadap masyarakat dan budaya (Rakhmat, 1998). Agenda setting menggambarkan pengaruh media yang sangat kuat terhadap pembentukan opini masyarakat, karena media memberi tekanan pada suatu peristiwa maka media itu akan memengaruhi khalayak untuk menganggapnya penting (Littlejohn, Stephen W. \& Foss, 2008). Cohen (1963) dalam Rakhmat (1998) mengemukakan asumsi dasar agenda setting sebagai berikut:

The press is significantly more than surveyor of information and opinion. It may not successful much of the time in telling the people what to think, but it is stunningly successful in telling readers what to think about.

Pernyataan Cohen tersebut merupakan dasar dari fungsi agenda setting dari media massa (Baran, 2010). Menurut Rakhmat (1998), "To tell what to think about..." mengandung pengertian membentuk persepsi khalayak tentang apa yang dianggap penting. Becker seperti dikutip Rakhmat (1998), dengan teknik pemilihan dan penonjolan, media memberikan petunjuk isu mana yang lebih penting. Oleh sebab itu, agenda setting mengasumsikan apa yang dianggap penting oleh media, akan dianggap penting pula oleh masyarakat. Apa yang dilupakan media, akan luput juga dari perhatian masyarakat (Rakhmat, 1998). McCombs dan Shaw dalam (Littlejohn, Stephen W.

$\&$ Foss, 2008) menggambarkan fungsi agenda setting sebagai berikut:

"Considerable evidence has accumulated that editors and broadcasters play an important part in shaping our social reality as they go about their day to day task of choosing and displaying news. 
This impact of mass media-the ability to effect cognitive change among individuals, to structure their thinking-has been labeled the agenda setting function of mass communication. Here may lie the most important effect of mass communication, its ability to mentally order and organize our world for us. In short, the mass media may not be successful in telling us what to think, but they are stunningly successful in telling us what to think about."

Pernyataan McCombs dan Shaw tersebut menjelaskan bahwa dalam memilih dan menentukan berita, editor dan staf memiliki peranan yang penting dalam membentuk realitas politik. Pembaca belajar tidak saja mengenai isu tertentu, tetapi juga seberapa penting untuk terikat pada isu tersebut berdasarkan jumlah informasi yang ada di berita. Media massa menentukan isu mana yang penting - media mengatur agenda dari berita. Atau dengan lebih singkat, agenda setting menetapkan isuisu yang menonjol dan gambaran tentang sesuatu di dalam pikiran masyarakat (Littlejohn, Stephen W. \& Foss, 2008).

McCombs dan Shaw menyimpulkan bahwa terdapat suatu hubungan yang kuat antara penekanan pada suatu isu yang dilakukan media (agenda media)

dengan pemilihan justifikasi tentang pentingnya suatu isu oleh publik (agenda publik) (Littlejohn, Stephen W. \& Foss, 2008). McCombs dan Shaw dalam (Littlejohn, Stephen W. \& Foss, 2008) juga menjelaskan bahwa dengan melihat isuisu yang dipublikasikan atau diberitakan oleh media secara terus-menerus, maka secara tidak langsung masyarakat akan berbagi pandangan dengan media dan melihat isu tersebut sebagai isu utama didalam agenda masyarakat. Penjelasan tersebut senada dengan (Hamad, 2004) yang mengemukakan besarnya perhatian masyarakat terhadap sebuah isu sangat bergantung seberapa besar media memberikan perhatian pada isu tersebut. Selanjutnya, jika satu atau sejumlah media menempatkan sebuah kasus pada halaman satu atau headline diasumsikan kasus itu pasti memperoleh perhatian yang besar dari khalayak.

McCombs dan Shaw percaya bahwa media massa memiliki kemampuan untuk mentransfer arti penting dari agenda berita ke agenda publik (Griffin, 2009). Gagasan McCombs dan Shaw mengenai agenda setting ini mencoba mengungkapkan betapa penting dan "powerful"-nya pengaruh media, terutama dalam kemampuannya mempengaruhi publik (Hamad, 2004). Selain itu, teori ini juga mengandung asumsi bahwa media tidak semata-mata mengabarkan opini dan informasi, melainkan perannya melebihi itu, media turut menyeleksi dan menentukan informasi maupun opini tersebut (Baran, 2010). Lebih lanjut, Baran (2010) menjelaskan media sebenarnya hanya berkonsentrasi pada isuisu tertentu yang jumlahnya sedikit dan kemudian membuat audiens menerima memang itulah isu-isu yang lebih penting dibanding dengan isu-isu lainnya. Salah satu dampak dari fungsi agenda setting ini adalah gambaran realitas yang menempel di benak masyarakat sebagaimana media mengontruksikannya.

Berdasarkan hal tersebut, McCombs dan Shaw menjelaskan tiga tahapan proses dalam agenda setting, yaitu pertama adalah prioritas masalah yang akan dibahas di media, atau agenda media, harus diatur sedemikian rupa. Kedua, agenda media dalam beberapa cara memengaruhi atau berinteraksi dengan apa yang masyarakat 
pikir, menciptakan agenda publik. Ketiga, agenda publik memengaruhi atau berinteraksi dalam beberapa cara dengan para pembuat kebijakan untuk mempertimbangkan penting atau tidak, hal ini disebut agenda kebijakan (Littlejohn, Stephen W. \& Foss, 2008).

McCombs dan Shaw menyatakan bahwa agenda media membuat suatu hubungan yang jelas antara isi media tertentu dan pengaruhnya di kalangan masyarakat. Agenda media mencoba menetapkan pentingnya sebuah isu atau konten media, yang diukur dengan frekuensi tampilnya isu tersebut di media. Sementara itu, Griffin (2009) menyatakan bahwa teori agenda setting ini adalah kemampuan media untuk menyeleksi dan mengarahkan perhatian masyarakat pada gagasan atau peristiwa tertentu. Media mengatakan pada kita apa yang penting dan apa yang tidak penting, media pun mengatur apa yang harus diilhat, tokoh siapa yang harus didukung. Lebih lanjut, Griffin (2009) menyatakan bahwa media massa selalu mengarahkan kita pada apa yang harus kita lakukan. Media memberikan agenda-agenda media melalui pemberitaannya, sedangkan masyarakat mengikutinya karena agenda publik di masyarakat sebenarnya berasal dari agenda media.

Beberapa ahli berpendapat bahwa agenda publik memiliki pengaruh dalam mengatur agenda media. Media melihat agenda publik melalui rating, penelitian pasar, pola konsumsi mengenai apa yang ingin dibaca dan ditonton oleh audiens, dan setelah itu hal tersebut direspons oleh media (Vivian, 2008). Dengan kata lain, media terdorong oleh kebutuhan pasar, oleh karena itu media berusaha memberikan audiens dengan apa yang diinginkan oleh audiens (Littlejohn, Stephen W. \& Foss,
2008). Selain itu, beberapa ahli lainnya seperti dikutip Littlejohn, Stephen W. \& Foss (2008) juga berpendapat bahwa sebenarnya politisi dan praktisi humas juga memiliki kontribusi dalam mengatur agenda media. Akan tetapi, pada intinya teori agenda setting mencoba menjelaskan bahwa dalam hal apa pun pada proses produksi media, tidak ada agenda media yang dibentuk dan diatur tanpa alasan yang kuat (Littlejohn, Stephen W. \& Foss, 2008).

Menurut Vivian (2008), agenda setting dapat terjadi pada beberapa level. Level yang pertama adalah penciptaan kesadaran, yaitu jika individu menyadari isu, ia baru akan memerhatikan isu. Kedua adalah menentukan prioritas, orang mempercayai berita dari media untuk mengetahui kejadian-kejadian dan mengurutkan kejadian-kejadian itu berdasarkan arti pentingnya. Berita halaman utama atau halaman satu koran dianggap sebagai berita paling signifikan. Agenda seseorang akan terkena pengaruh bukan hanya dari cara suatu berita ditampilkan atau disampaikan, tetapi juga waktu dan ruang yang disediakan untuk berita tersebut. Yang ketiga adalah mempertahankan isu liputan terusmenerus akan membuat isu menjadi terlihat penting. Namun, akan terjadi sebaliknya apabila gatekeeper media beralih ke berita lain, sebuah isu panas akan segera usang dalam semalam atau segera dilupakan orang.

\section{Konstruksi Realitas}

Konstruksi sosial adalah teori yang diperkenalkan oleh Peter L Berger dan Thomas Luckmann (Sobur, 2009). Teori ini merupakan perkembangan dari teori fenomenologi yang pada awalnya dirintis oleh Hegel, Husserl, dan dilanjutkan oleh Schutz (Basrowi \& Sukidin, 2003). 
Kontruksi sosial yang digagas oleh Berger dipengaruhi fenomenologi Schutz, namun Berger keluar jauh dari fenomenologi Schutz yang dianggap hanya berkutat pada makna sosialitas (Poloma, 2004). Berger dan Luckmann memulai penjelasan realitas sosial dengan memisahkan pemahaman tentang "kenyataan" dan "pengetahuan" (Sobur, 2009). Dua istilah inilah yang menjadi kunci teori konstruksi sosial. Kenyataan adalah suatu realitas yang terdapat dalam fenomena-fenomena yang memiliki keberadaan (being) yang tidak bergantung pada kehendak individu manusia. Sementara itu, pengetahuan adalah kepastian bahwa realitas-realitas itu nyata (real) dan memiliki karakteristik yang spesifik (Sobur, 2009). Selain itu, mereka juga menjelaskan realitas sosial yang bersifat keseharian seperti konsep, kesadaran umum, dan wacana publik merupakan hasil dari kontruksi sosial (Bungin, 2007). Berger dan Luckman seperti dikutip Eriyanto (2011) juga menyatakan kenyataan itu sendiri bersifat plural, dinamis, dan dialektis. Artinya, realitas atas peristiwa dari seseorang mungkin tidak akan sama dengan realitas orang lain.

Proses dialektis tersebut mempunyai tiga tahapan peristiwa. Berger dan Luckmann dalam (Eriyanto, 2011) menyebut tahapan tersebut dengan momen, yaitu:

1. Eksternalisasi, yakni usaha untuk pencurahan atau ekspresi diri manusia ke dalam dunia, baik dalan kegiatan mental maupun fisik. Ini sudah menjadi sifat dasar dari manusia. Ia akan selalu mencurahkan diri ke tempat di mana ia berada. Pada tahap ini manusia mengalami proses penyesuaian diri dengan dunia sosiokultural sebagai produk manusia. Dalam konteks ini, menurut (Tamburaka, 2013) informasi dari media massa merupakan produk sosial yang dibutuhkan oleh individu atau khalayak untuk memaknai lingkungan sosialnya.

2. Objektivasi, yakni hasil yang telah dicapai baik mental maupun fisik dari kegiatan eksternalisasi.

Pencapaian tersebut menghasilkan realitas objektif yang bisa jadi akan menghadapi itu sendiri sebagai suatu aktivitas yang berada di luar dan berlainan dari manusia yang menghasilkannya. Ini adalah tahap interaksi sosial yang terjadi dalam dunia intersubjektif yang dilembagakan atau mengalami proses institusionalisasi. Tahapan objektivasi ini dilakukan dengan signifikasi bahasa (Tamburaka, 2013).

3. Internalisasi, proses ini lebih merupakan penyerapan kembali dunia objektif ke dalam kesadaran sedemikian rupa sehingga subjektif individu dipengaruhi oleh struktur dunia sosial. Berbagai macam unsur dari dunia yang telah terobjektifkan tersebut akan ditangkap sebagai gejala realitas diluar kesadarannya, sekaligus sebagai gejala internal bagi kesadaran. Melalui proses internalisasi manusia menjadi hasil dari masyarakat.

Menurut Eriyanto (2011), realitas tidak dibentuk secara ilmiah tetapi dibentuk dan dikontruksikan. Realitas sosial yang dikontruksi secara berbeda oleh masing-masing individu ini dipengaruhi oleh pengalaman, preferensi, latar belakang pendidikan tertentu, 
lingkungan pergaulan, dan sosial (Eriyanto, 2011). Hal tersebut sejalan dengan Basrowi \& Sukidin (2003) yang menjelaskan ketika individu menanggapi kejadian

di sekitarnya berdasarkan pengalaman mereka, itulah yang disebut dengan kontruksi realitas secara sosial. Lebih lanjut, Basrowi juga mengemukakan individu yang dimaksud adalah manusia bebas yang melakukan hubungan antara manusia yang satu dengan yang lainnya.

Individu menjadi penentu dalam dunia sosial yang dikontruksi berdasarkan kehendaknya. Ia juga menambahkan bahwa individu bukanlah fakta sosial, namun sebagai media produksi sekaligus reproduksi yang kreatif dalam mengontruksi dunia sosialnya (Basrowi \& Sukidin, 2003). Sementara itu, (Ngangi, 2011) dalam tulisannya mengungkapkan kontruksi sosial merupakan sebuah pandangan kepada kita bahwa semua nilai, ideologi, dan institusi sosial adalah buatan manusia. Menurut Berger dan Luckmann dalam (Bungin, 2007), rekontruksi sosial terdiri dari tiga macam. Pertama, realitas objektif, yaitu realitas yang terbentuk dari pengalaman di dunia objektif yang berada di luar diri individu, dan realitas ini dianggap sebagai kenyataan. Kedua, realitas simbolik, merupakan ekspresi simbolik dari realitas objektif dalam berbagai bentuk. Ketiga, realitas subjektif, yaitu realitas yang terbentuk sebagai proses penyerapan kembali realitas objektif dan simbolik ke dalam individu melalui proses internalisasi.

Oleh sebab itu, sebagai hasil dari kontruksi sosial maka realitas menurut Berger dalam (Eriyanto, 2011) memiliki sifat subjektif dan objektif. Selanjutnya, Berger menjelaskan realitas subjektif itu sendiri menyangkut makna, interpretasi, dan hasil relasi antara individu dan objek. Sementara itu, realitas objektif merupakan faktor yang berada di luar atau eksternal. Menurut Ngangi (2011), kontruksi sosial juga memiliki beberapa kekuatan, yaitu pertama, terdapat pada peran sentral bahasa memberikan mekanisme konkret, di mana budaya memengaruhi pikiran dan tingkah laku individu. Kedua, kontruksi sosial dapat mewakili kompleksitas dalam suatu budaya tunggal, hal ini tidak mengasumsikan keseragaman. Ketiga, hal ini bersifat konsisten dengan masyarakat dan waktu.

\section{Metode Penelitian}

Penelitian ini menggunakan pendekatan kualitatif. Menurut (Kriyantono, 2012), penelitian kualitatif merupakan suatu proses penelitian dan pemahaman berdasarkan pada metodologi yang menyelidiki fenomena sosial dan masalah manusia. Creswell seperti dikutip (Kriyantono, 2012) mengemukakan bahwa dalam pendekatan ini peneliti membuat suatu gambaran kompleks, meneliti katakata, laporan terinci dan pandangan responden serta melakukan studi pada situasi yang dialami. Sementara itu, Bogdan dan Taylor menyampaikan bahwa prosedur penelitian menghasilkan data deskriptif berupa kata-kata tertulis 
maupun lisan dan perilaku dari orangorang yang diamati.

Menurut Kriyantono (2012), penelitian dengan pendekatan kualitatif mempunyai ciri-ciri sebagai berikut:

1. Intensif, partisipasi periset dalam waktu lama pada setting lapangan, periset adalah instrumen pokok riset.

2. Perekaman yang sangat hatihati terhadap apa yang terjadi dengan catatan-catatan di lapangan dan tipe-tipe lain dari bukti-bukti dokumenter.

3. Analisis data lapangan.

4. Melaporkan hasil termasuk deskripsi detail, quotes (kutipan) dan komentar-komentar.

5. Tidak ada realitas yang tunggal, setiap periset mengkreasi realitas sebagai bagian dari proses risetnya. Realitas dipandang sebagai sesuatu yang dinamis dan produk kontruksi sosial.

6. Subjektif dan berada hanya dalam referensi periset. Periset sebagai sarana penggalian interpretasi data.

7. Realitas adalah holistic dan tidak dapat dipilah-pilah.

Bungin (2007) mengemukakan bahwa penelitian dengan pendekatan metode kualitatif memiliki tujuan untuk menganalisis proses berlangsungnya suatu fenomena sosial dan memperoleh gambaran yang tuntas terhadap proses tersebut. Tujuan lainnya, menurut Bungin, menganalisis makna yang ada di balik informasi data dan proses suatu fenomena sosial itu. Berdasarkan tujuan-tujuan tersebut, Bungin (2007) membagi tiga kelompok besar metode analisis data kualitatif, yaitu pertama, kelompok metode analisis teks dan bahasa. Kedua, kelompok analisis tema-tema budaya. Ketiga, kelompok analisis kinerja dan pengalaman individu serta perilaku institusi.

Penelitian ini menggunakan metode penelitian kualitatif yang dilakukan secara eksploratif dengan melakukan pengamatan terhadap foto-foto kampanye pemilihan kepala daerah DKI Jakarta putaran kedua yang dipublikasikan oleh dua surat kabar nasional Kompas dan Republika. Pengamatan dilakukan dengan melihat frekuensi pemberitaan berdasarkan penempatan halamannya seperti halaman satu (headline), halaman dalam (nonheadline), iklan kampanye, dan "spot" khusus atau halaman khusus. Selain itu, pengumpulan dan analisis data dilakukan dengan studi literatur, dokumen, dan wawancara tidak terstruktur terhadap para fotografer dan redaktur foto serta responden atau informan yang mewakili publik.

\section{Objek Penelitian}

Fotografi jurnalistik merupakan salah satu komponen konten yang sangat penting dalam surat kabar. Oleh sebab itu, tulisan ini bertujuan untuk melihat seberapa besar dampak foto jurnalistik dalam memengaruhi opini pemilih di pemilihan kepala daerah DKI Jakarta. Data yang dianalisis adalah foto-foto kampanye pasangan calon Pemilihan Kepala Daerah (Pilkada) DKI Jakarta terhitung sejak masa kampanye putaran kedua dari 7 Maret 2017 sampai dengan 15 April 2017. Data ini merupakan foto yang dipublikasikan oleh dua surat kabar nasional. Surat kabar nasional tersebut adalah Kompas dan Republika.

Pertimbangan pemilihan surat kabar tersebut karena kedua surat kabar nasional ini dinilai dapat mewakili suara aspirasi dari berbagai kelompok masyarakat. Misalnya, pemberitaan Kompas identik menyuarakan suara golongan minoritasSed, sedangkan 
Republika identik dengan menyampaikan suara golongan mayoritas. Selain itu, alasan dipilihnya surat kabar ini adalah pertama, kedua surat kabar nasional ini merupakan surat kabar nasional yang sering dimanfaatkan oleh para kandidat dan partai politik untuk memublikasikan programprogramnya ke khalayak luas. Kedua, surat kabar ini merupakan surat kabar yang memiliki visi dan misi yang jelas bila dibandingkan dengan surat kabar lain yang tampak tidak konsisten dalam menjalankan kebijakannya. Dari segi manajemen, kedua surat kabar nasional ini juga dinilai memiliki tingkat kemapanan dari sisi ekonomi, segmen, dan kebijakan redaksional.

\section{PEMBAHASAN}

Visualisasi

peristiwa yang diterjemahkan dalam karya foto jurnalistik merupakan bagian dari usaha untuk mengonstruksi realitas. Foto-foto yang yang dipublikasikan dalam surat kabar tersebut memiliki makna tersendiri bagi para khalayak. Foto jurnalistik memiliki peranan yang sangat penting dalam mengabadikan sebuah peristiwa. Kemampuan fotografisnya tidak saja memungkinkan merekam gambar secara realis, namun juga mampu merekam gambar dalam hitungan detik. Karena kemampuan inilah yang membuat fotografi jurnalistik memiliki peranan yang strategis dalam surat kabar. Peran strategis fotografi jurnalistik dimanfaatkan oleh para kandidat calon kepala daerah DKI Jakarta dan para partai pendukung untuk memengaruhi opini khalayak atau publik.

Berdasarkan pada pengamatan frekuensi publikasi foto jurnalistik terhadap para pasangan calon kepala daerah DKI Jakarta putaran kedua di surat kabar Kompas dan Republika, diperoleh data sebagai berikut.

\begin{tabular}{ccc}
$\begin{array}{c}\text { Frekuensi } \\
\text { Publikasi }\end{array}$ & $\begin{array}{c}\text { Basuki \& } \\
\text { Djarot }\end{array}$ & $\begin{array}{c}\text { Anies \& } \\
\text { Sandi }\end{array}$ \\
\hline $\begin{array}{c}\text { Halaman } \\
\text { Satu }\end{array}$ & 1 kali & 1 kali \\
$\begin{array}{c}\text { Halaman } \\
\text { Dalam } \\
\text { Iklan }\end{array}$ & 5 kali & 4 kali \\
$\begin{array}{c}\text { Kampanye } \\
\text { Halaman } \\
\text { khusus }\end{array}$ & 1 kali & 1 kali \\
\hline Total & --- & --- \\
\hline
\end{tabular}

Tabel 1

Frekuensi Publikasi Pasangan Kandidat Pilkada DKI Jakarta pada masa kampanye putaran kedua di Surat Kabar Kompas, 7 Maret-15 April 2017.

Tabel tersebut memperlihatkan perbandingan jumlah frekuensi publikasi kedua kandidat pasangan calon kepala daerah DKI Jakarta. Meski hanya terpaut satu angka, jumlah total frekuensi publikasi pasangan Basuki Tjahaya Purnama dan Djarot Saiful Hidayat dalam surat kabar Kompas terlihat lebih unggul bila dibandingkan dengan pasangan Anies Baswedan dan Sandiaga Uno. Jumlah total frekuensi untuk Basuki Tjahaya Purnama dan Djarot Saiful Hidayat memiliki nilai tujuh, sedangkan Anies Baswedan dan Sandiaga Uno memiliki nilai enam.

Namun, foto kedua kandidat pasangan calon kepala daerah DKI Jakarta pada masa kampanye putaran kedua ini banyak menghiasi halaman dalam terutama yang berkaitan dengan liputan perkotaan (metropolitan). Di halaman tersebut, pasangan Basuki Tjahaya Purnama dan Djarot Saiful Hidayat tercatat lima kali. Pasangan Anies Baswedan dan Sandiaga Uno tercatat tiga kali di halaman metropolitan dan satu kali di halaman politik dan hukum. Untuk halaman pertama atau headline, kedua pasangan calon kepala daerah masing-masing dimuat satu kali. Sementara itu, untuk 
pemasangan iklan kampanye di Kompas kedua pasangan kandidat juga memiliki kesamaan satu kali.

\begin{tabular}{ccc}
\hline $\begin{array}{c}\text { Frekuensi } \\
\text { Publikasi }\end{array}$ & $\begin{array}{c}\text { Basuki \& } \\
\text { Djarot }\end{array}$ & $\begin{array}{c}\text { Anies \& } \\
\text { Sandi }\end{array}$ \\
\hline Halaman & 2 kali & 2 kali \\
Satu & Halaman & 4 kali \\
Dalam & -- & -- \\
Iklan & -- & -- \\
$\begin{array}{c}\text { Kampanye } \\
\text { Halaman } \\
\text { Khusus }\end{array}$ & -- & 6 kali \\
\hline Total & 2 kali & \\
\hline
\end{tabular}

Tabel 2

Frekuensi Publikasi Pasangan Kandidat Pilkada DKI Jakarta pada masa kampanye putaran kedua di Surat Kabar Republika,7 Maret-15 April 2017

Hasil pengamatan frekuensi publikasi disuratkabarRepublika menunjukkanhasil yang berbeda dengan surat kabar Kompas. Frekuensi pemberitaan bila ditinjau secara total, pasangan calon Anies Baswedan dan Sandiaga Uno unggul bila dibandingkan dengan pasangan Basuki Tjahaya Purnama dan Djarot Saiful Hidayat. Selisih di antara keduanya cukup jauh berbeda, kandidat pasangan Anies Baswedan dan Sandiaga Uno tercatat dipublikasikan sebanyak enam kali, sedangkan kandidat pasangan Basuki Tjahaya Purnama dan Djarot Saiful Hidayat hanya dipublikasikan dua kali. Foto kampanye kandidat pasangan Anies Baswedan dan Sandiaga Uno banyak dimuat di halaman dalam. Untuk halaman satu atau headline kedua pasangan calon sama-sama dimuat sebanyak dua kali. Dalam iklan kampanye, sampai pada hari terakhir masa kampanye, kedua kandidat tidak terlihat memasang iklan kampanye mereka di Republika.
Intensitas frekuensi publikasi yang berbeda antara Kompas dan Republika pada masa kampanye menunjukkan bahwa kedua surat kabar ini memiliki agenda yang berbeda dalam melakukan konstruksi terhadap pemberitaannya. Kompas secara umum bisa dikatakan telah melakukan pemberitaan secara seimbang terhadap kedua pasangan calon. Hal tersebut berdasarkan pada perbedaan jumlah total frekuensi publikasi kedua pasangan calon yang tidak mengalami selisih secara signifikan, hanya terpaut atau selisih satu angka. Sementara itu, frekuensi publikasi di Republika terlihat surat kabar ini condong terhadap pasangan calon Anies Baswedan dan Sandiaga Uno. Pasangan Anies Baswedan dan Sandiaga Uno mendapatkan porsi lebih besar bila dibandingkan dengan pasangan Basuki Tjahaya Purnama dan Djarot Saiful Hidayat. Jumlah total frekuensi publikasi pasangan Anies Baswedan dan Sandiaga Uno dan pasangan Basuki Tjahaya Purnama dan Djarot Saiful Hidayat memiliki selisih empat angka.

Berdasarkan hasil pengamatan terhadap frekuensi publikasi foto jurnalistik di dua surat kabar nasional tersebut di atas menunjukkan bahwa kedua surat kabar tersebut memberikan perhatian atau penekanan yang berbeda terhadap kedua pasangan kandidat kepala daerah DKI Jakarta. Menurut McCombs dan Shaw, penekanan yang lebih terhadap salah satu isu atau pemberitaan menunjukkan bahwa media memiliki keinginan untuk membentuk persepsi khalayak mengenai apa yang dianggap penting oleh media tersebut. Dengan demikian, jika ditelaah berdasarkan frekuensi publikasi di atas, penekanan atau publikasi yang lebih terhadap salah satu calon oleh Republika dapat diasumsikan bahwa surat kabar 
tersebut melalui foto jurnalistik yang dipublikasikan memiliki keinginan untuk membentuk persepsi khalayak terhadap salah satu calon pasangan tertentu. Hal ini sejalan seperti dalam agenda setting yang menyatakan bahwa apa yang dianggap penting oleh media, akan dianggap penting pula oleh masyarakat. Apa yang dilupakan media, akan luput juga dari perhatian masyarakat (Rakhmat, 1998). Isu-isu yang dipublikasikan atau diberitakan oleh media secara terusmenerus, membuat masyarakat akan berbagi pandangan dengan media dan melihat isu tersebut sebagai isu utama di dalam agenda masyarakat. Dengan demikian, hal tersebut memiliki efek atau dampak memengaruhi opini masyarakat.

Sementara itu, proses kontruksi realitastidaklepasdariperanandariindividu yang terlibat dalam proses kontruksi. Dalam dunia fotografi jurnalistik, individu tersebut adalah wartawan foto yang bekerja di surat kabar. Wartawan foto melakukan peliputan terhadap berbagai peristiwa yang terjadi dan mengonstruksikannya berdasarkan pengalaman, latar belakang, dan pengetahuannya. Terkait dengan foto-foto jurnalistik yang dipublikasikan oleh Kompas dan Republika, para wartawan foto terlibat dalam proses kontruksi realitas pada saat para kandidat calon kepala daerah DKI Jakarta melakukan kampanye dan sosialisasi program-programnya.

Beberapa foto yang dipublikasikan di kedua surat kabar tersebut menampilkan interaksi kedua kandidat calon kepala daerah dengan para pendukungnya di beberapa daerah di Jakarta. Melihat foto yang dipublikasikan tersebut, ada beberapa aspek yang dapat berpengaruh terhadap hasil konstruksi realitas, antara lain sudut pandang atau angle, framing, komposisi, warna, pencahayaan, dan momen dalam setiap peristiwa. Menurut redaktur foto harian Republika, Yogi Ardhi, beberapa aspek teknis di atas juga turut membantu masyarakat dalam menginterpretasikan foto-foto yang ditampilkan Republika. Meski menurutnya tidak semua khalayak memiliki interepretasi yang sama, paling tidak hal tersebut dapat membantu khlayak memahami makna dari kontruksi realitas yang dihadirkan oleh para wartawan foto.

\section{SIMPULAN}

Berdasarkan hasil penelitian dan pembahasan di atas dapat disimpulkan bahwa surat kabar Kompas dan Republika dalam menjalankan pemberitaan memiliki agenda yang berbeda. Meski pada pemberitaannya tampak memihak salah satu kandidat calon kepala daerah, Kompas masih memberikan porsi yang sama untuk publikasi dari pasangan kandidat calon kepala daerah yang lain. Hal ini secara umum tidak cukup memberikan dampak terhadap pembentukan opini publik. Tampaknya, ada kebijakan redaksi untuk tidak melakukan keberpihakan secara terbuka, mengingat pada waktu itu salah satu calon sedang menjalani proses persidangan dugaan penistaan agama sehingga pemberitaannya tidak terlalu gencar. Berbeda dengan Republika, surat kabar ini telah memberikan perhatian lebih terhadap salah satu pasangan kandidat calon kepala daerah DKI Jakarta. Pemberitaan yang ditampilkan dalam bentuk visual foto jurnalistik banyak didominasi oleh pasangan Anies Baswedan dan Sandiaga Uno. Untuk rivalnya, pasangan Basuki Tjahaya Purnama dan Djarot Saiful Hidayat hanya diberikan sedikit publikasi. Publikasi diberikan tidak untuk kampanye program mereka, tetapi pemberitaan mengenai proses persidangan kasus dugaan penistaan agama yang melibatkan kandidat calon kepala daerah 
Basuki Tjahya Purnama. Dengan demikian, foto jurnalistik akan memiliki dampak atau pengaruh untuk membentuk opini publik atau pemilih apabila foto mengenai sebuah isu diberitakan secara terus-menerus oleh media.

\section{KEPUSTAKAAN}

Baran, S. J. (2010). Introduction to Mass Communication: Media Literacy and Culture. New York: McGraw Hill.

Basrowi \& Sukidin. (2003). Metode Penelitian Perspektif Mikro: Grounded Theory, Fenomenologi, Etnometodologi, Etnografi, Dramaturgi, Interaksi Simbolik, Hermeneutik, Kontruksi Sosial, Analisis Wacana, dan Metodologi Refleksi. Surabaya: Insan Cendekia.

Bungin, M. B. (2007). Penelitian Kualitatif: Komunikasi, Ekonomi, Kebijakan Publik, dan Ilmu Sosial Lainnya. Jakarta: Kencana Prenada Media Group.

Eriyanto. (2011). Analisis Framing: Konstruksi, Ideologi, dan Politik Media. Yogyakarta: Lkis.

Griffin, E. (2009). First Look at Communication Theory. New York: McGraw Hill.

Hamad, I. (2004). Konstruksi Realitas Politik dalam Media Massa: Sebuah Studi Critical Discourse Analysis terhadap Berita-berita Politik Edisi I. Jakarta: Granit.

Kriyantono, R. (2012). Teknik Praktis Riset Komunikasi. Jakarta: Kencana.

Littlejohn, Stephen W. \& Foss, K. A. (2008). Teori Komunikasi:Theories of Human Communication. Edisi 9. Terj. Mohammad Yusuf Hamdan. Jakarta: Salemba Humanika.

Ngangi, C. R. (2011). Kontruksi Sosial dalam Realitas Sosial. Jakarta: ASE Journal, Volume $7 \mathrm{~N}$.

Poloma, M. (2004). Sosiologi Kontemporer. Jakarta: PT Raja Grafindo Persada.
Rakhmat, J. (1998). Metode Penelitian Komunikasi. Bandung: PT Rosdakarya.

Sobur, A. (2009). Analisis Teks Media: Suatu Pengantar untuk Analisis Wacana, Analisis Semiotik, dan Analisis Framing. Bandung: PT Remaja Rosdakarya.

Tamburaka, A. (2013). Agenda Setting Media Massa. Depok: PT Rajagrafindo Persada.

Vivian, J. (2008). Teori Komunikasi Massa. Jakarta: Kencana. 